\title{
O PROBLEMA DA SOBERANIA E O DIREITO DAS GENTES
}

\author{
Nelson Luz \\ Professor de Direito Internacional Público da Fa- \\ culdade de Direito da Universidade do Paraná.
}

Não é indiscutívelmente aceita pelos autores a etimologia do têrmo soberania. Provàvelmente tem sua origem na expressão latina super omnia, ou no vocábulo do baixo latim superanus; ou ainda, supremitas ou suprema potestas, vocábulos que, de um modo geral, exprimiam um poder, antes comparativo e após superlativo, sòmente limitado pelo poder de Deus.

Conquanto se possa conceber o conceito de soberania mesmo em ambientes extra-estatais (soberania familiar ou de índole religiosa), ela é, diz MACHADO PAUPÉRIO, "por sua essência, pública", entendida assim como "a característica histórica e racional que distingue 0 poder político", na expressão de ADOLFO POSADA. Porisso constitui "a fonte da capacidade jurídica do Estado", segundo CHIMIENTI.

Sendo causa formal do Estado, caracteriza-se especìficamente como o poder de uma coletividade no sentido de realizar, para o grupo social, a condição de sua auto-suficiência.

Ora, o Estado é uma coletividade que, em determinado território, se organiza politicamente. Baseia-se, assim, no conceito de CARRÉ DE MALBERG, "não já sôbre uma associação entre os indivíduos, mas sôbre a organização estatal mesma", tendo por efeito englobar os elementos individuais da nação num corpo único. Através dos seus órgãos, exerce, então, o Estado as suas atribuições com as características de "personalidade", não real, mas jurídica, e portanto, "abstrata, mas não fictícia". $\mathrm{E}$ o que transforma a coletividade em pessôa é a "capacidade de direitos própria". 
Se atentarmos, todavia, para tal atributo de "personalidade", concluiremos pelo seguinte: ela não basta para caracterizar o Estado, pois encontramos a "pessôa" em várias sociedades de direito privado. O que irá configurar o Estado é o fato de que o poder lhe é próprio. A êsse poder a terminologia francesa denominou de soberania.

Assim, em sua mais nítida interpretação, soberania não equivale estritamente a poder, mas a uma certa forma de poder, ou, mais explicadamente, a um certo gráu de poder. Um Estado é, portanto, soberano, quando, exercendo seu poder na esfera das suas atribuições, não está sujeito a outro poder igual ou superior.

Conquanto essencialmente una, apresenta-se a soberania sob dois aspectos conhecidos: interno e externo. O que configura a soberania interna é a autoridade suprema do Estado sôbre os seus indivíduos ou as associações públicas ou privadas formadas no território, autoridade assim entendida no sentido de que não há vontade superior a ela. A soberania externa afirma-se pelo fato de que o Estado está excluido de tôda subordinação com referência a outros Estados, ou melhor, é independente.

Desde já é, pois, possível conceituar a soberania como uma qualidade de poder, pois é supremacia, manifestação absoluta, que se exerce, entretanto, na esfera de sua competência, e apenas nela.

De tal conceito surgem as regras seguintes: $10^{\circ}$ ) - a soberania é una, porque não admite poder igual ou superior ao seu; $2 .^{\circ}$ ) - é indivisivel, porque pertence exclusivamente ao Estado; $3^{\circ}$ ) - é inalienável e imprescritível porque, como diz QUEIROZ LIMA, "representa a própria personalidade da nação".

Para JELLINEK, entretanto, a soberania não é poder do Estado ou autoridade pública, e sim um aspecto especial dessa autoridade. Com referência ao Estado, segundo LABAND, "a determinação de sua própria competêncía, que se póde chamar 
a competência da competência, é o critério próprio e essencial da soberania". E', assim, o poder que tem o Estado para limitar a sua própria competência.

O conceito alemão não se afasta dêste último ponto de vista. Apenas os doutrinadores alemães substituem o titular do direito de soberania; e aparece, em vez da soberania nacional, a nação órgão. Se, para a escola francesa, é a nação o titular da soberania, já para a escola alemã o titular é o Estado, sendo a nação simples elemento que o compõe, muito embora se reconheça que é ela o órgão, no Estado, pelo qual se realiza ou exerce a soberania.

HANS KELSEN, admitindo, sob certo aspecto, o Estado como o ponto final da imputação jurídica, como criação lógico-normativa, identifica-o ao Direito. A soberania “é a propriedade de ser de uma ordem suprema, uma ordem que já não deve a sua validade a uma ordem superior". Em última análise, portanto, o titular da soberania é o próprio Direito.

Estabelecido, assim, o conceito de soberania como sendo uma qualidade de poder, suprema na sua esfera de ação, pretendemos a solução do seguinte: quais as possibilidades de limitação dêsse poder?

CARRÉ DE MALBERG ataca de frente a questão. "A teoria moderna do Estado já penetrada da idéia de que o poder de dominação estatal, por ser um poder de natureza jurídica, é porisso mesmo um poder submetido ao Direito, e portanto necessàriamente um poder limitado". Após a Revolução Francesa o Estado aparece como pessôa distinta da dos governantes, e portanto sujeito à disciplina jurídica. Não seja esquecida, além disso, a idéia moderna de que o indivíduo, como diz ESMEIN, têm direitos anteriores e superiores ao Estado, e que por êste devem ser respeitados, idéia consolidada pela Revolução Francesa, que admitia o Estado limitado pelos direitos fundamentais de igualdade e liberdade. O Estado não deve, assim, constituir um fim em si mesmo, mas um meio para o desenvolvimento da sociedade em seus vários aspectos. 
Êstes últimos pensamentos encontram correspondência na doutrina de Kelsen. Por ela, a pessôa do Estado é uma expressão hipotética que designa o sistema de ordem jurídica. A competência do Estado é, pois, limitada à conformidade com a ordenação jurídica.

A soberania de outros Estados implica também limitação à soberania. Sob êsse aspecto, NIEMEYER admite, perante 0 Direito das Gentes, duas manifestações do problema: $1 .^{\circ}$ ) soberania como "ausência de certas limitações e de existência de certas faculdades positivas de um Estado em relação aos outros Estados sob um aspecto de igualdade; $2 .^{\circ}$ ) - soberania no sentido da mais alta competência jurídica para o estabelecimento das relações internacionais dos Estados".

Com referência ao primeiro caso, comenta, seguindo LISZT, a capacidade ilimitada de realizar atos com consequências jurídicas atribuida aos Estados soberanos, tidos como tais os que possuem capacidade jurídica, capacidade de obrar e capacidade legislativa. Aos Estados semi-soberanos cabem, assim, certas limitações à soberania, limitações essas de ordem quantitativa apenas.

Quanto ao segundo caso, cita sòmente as palavras de LAPRADELLE: "Perante a soberania dos Estados acaba de afirmar-se uma nova soberania: a da justiça!"

Fica, portanto, o problema estabelecido da seguinte maneira: a soberania, na comunidade dos povos, cabe a ela mesma ou aos Estados? A solução é simples: permanecendo a soberania do Estado, só é possível estabelecer-se uma Liga; e se um Estado cede sua soberania a um organismo superior, estabelece-se uma Confederação. Não há, entretanto, para NIEMEYER, incompatibilidade entre a "competência da competência" e a "participação internacional".

A doutrina de KELSEN, antes citada, ao admitir o monismo jurídico, combate o conceito de soberania do Estado, pois, quando qualifica uma ordem jurídica de soberana, dá-lhe, porisso mesmo, o caráter de ordem total. E porque considera uno o sistema normativo, não póde admitir sistemas de regras se- 
não hierarquizados. Assim, por êsse critério, a soberania do Estado seria total, isto é, não poderia admitir outra ordem superior (no caso, a do Direito das Gentes). E a própria existência jurídica de outro Estado, aceita através do "reconhecimento", nada mais seria de que manifestação de um "direito nacional externo". Ora, isto seria negar a igualdade jurídica dos Estados. Portanto, para que se conceba a coexistência dos Estados nêsse sentido de igualdade, há que reconhecê-la num sistema jurídico convergindo para uma ordem total, que é internacional e soberana.

Daí, no dizer de KELSEN, só haver um único sistema de direito na fase atual das realidades jurídicas, e que é a ordem internacional.

Por consequência, só se póde falar em soberania do Estado, admitida a "pirâmide de competências", sob o ponto de vista da competência do Estado em estabelecer um ordenamento jurídico dizendo respeito a uma coletividade hieràrquicamente sujeita ao organismo total.

Por último, poderá ser dito que, embora lógica, a concepção kelseniana é, apenas, um ponto de vista na investigação doutrinária. Mas é como diz WILCHES: "é suficiente aceitar a realidade de que os indivíduos são os destinatários únicos de tôda norma jurídica; que é sôbre os sêres humanos que convergem as regulamentações jurídicas, para compreender a unidade fundamental do Direito e vêr que entre suas diversas disciplinas não existem diferenças essenciais, mas sòmente gráus de hierarquia".

Já FRANCISCO DE VITÓRIA previra a configuração da competência estatal, concebendo-a como emanação do Direito das Gentes.

A infra-estrutura das coletividades internacionais há muito perdura sem solução jurídica. Porisso, o Estado soberano, como concepção individualista, tende a desaparecer, pois está cumprida a função histórica das nacionalidades. "A principal das crises contemporâneas - diz WILCHES - é a ausência de correspondência entre o tipo jurídico de organização estatal e as exigências peremptórias de infra-estrutura supra-nacional". 
A realidade não é senão uma: o mundo contemporâneo está a exigir uma renovação de valores. 0 problema universal nunca esteve tão ligado aos interesses individuais como em nosso tempo. A ciência evoluida e o domínio do espaço trouxeram situações que estão a exigir uma solução imediata.

Entretanto, permanece o dique da concepção de Estado soberano. Permanecem, aqui e alí, disseminadas ainda por misoneístas ortodoxos, as doutrinas voluntaristas da "auto-limitação". A própria dialética Hegeliana, filosòficamente baseada num "devenir" Fichteano, e, por consequência, caracterìsticamente dinâmica, imbui-se, insuflada pela política facciosa, de atributos estáticos ao esbarrar na formação estatal. Daí não admitir, como seria lógico, o super-Estado formado pelo concêrto das nacionalidades mas o super-Estado formado por uma nacionalidade.

* Portanto, "soberania absoluta do Estado de Direito Internacional são têrmos antagônicos".

Há, pois, que se aceitar, necessàriamente, uma revisão do conceito de soberania. E revisão no sentido de que ela não é atributo da própria natureza do Estado, mas uma "competência" conferida pelo Direito das Gentes.

E é possível mesmo, observada a soberania sob o aspecto isolado de competência atribuida ao Estado, conceber a êste (obrigatòriamente admitida a transformação do conceito clássico daquele têrmo) como soberano, isto é, capaz, ilimitadamente, de estabelecer todos os ordenamentos que dizem respeito à sua esfera de ação.

Com o primado do Direito das Gentes, pois, persiste a soberania estatal. Requer-se, apenas, que o conceito não tenha a mesma configuração clássica aludida; e que o Estado exerça, na hierarquia normativa, tão sòmente as atribuições de sua competência (não competência da competência, mas competência delegada), para mais lógica e mais justa consecução dos ideais humanos. 
A nosso vêr, a soberania do Estado, desde há muito, deixou de ser apenas uma questão de solução jurídico-política, parà tornar-se numa verdadeira mística, a insuflar patriotismos exaltados que, como tais, impedem a necessária visão dos direitos da humanidade considerada em seu conjunto.

Já muitos autores, em épocas diversas, mostraram ser a concepção da "competência da competência", limitada pelas fronteiras asfixiantes dos nacionalismos, o maior entrave para a evolução do Direito Internacional. 0 ambiente leigo já sinonimiza soberania com o amor à terra, às tradições, ao racismo, ao ufanismo dos elementos geradôres da nação. Os discursos de praça pública, quando pretendem acicatar os brios populares, sempre lançam, em alto e bom tom, através os trancelins de ouro dos verbos inflamados, o sagrado dever da pátria, os compromissos de honra para com a soberania; esquecidos de que ou a liberdade é um conceito limitado, ou deixa de ter sentido.

Não nos resta dúvida de que o principal problema em que nos debatemos sempre, é o problema da paz. Insustentável e utópica seria uma paz nacional se ignorássemos as soluções para uma paz internacional. Se o Estado, como comenta Darcy Azambuja, "é um meio para o homem realizar a sua felicidade social, é um sistema para conseguir a paz e a prosperidade"; se o fim do Estado, no dizer de Giorgio Loris, "é a tutela do Direito e a manutenção da paz", outro problema surge, de maior relevância, que é o da ambientação necessária dos Estados num sistema normativo e de paz universal.

"Quando se projeta a questão de como se poderia assegurar a paz - diz Hans Kelsen, - de como se poderia eliminar o emprêgo mais terrível da fôrça - isto é, a guerra das relações entre os Estados, nenhuma resposta póde ser mais evidente por si mesma do que esta: unindo a todos os Estados singulares, ou pelo menos o maior número possível em um Estado Mundial". Seria de mister, como acentúa Casimir Maciejewski, "a formação de organismos políticos de uma categoria mais alta do que o Estado". 
Todavia reconhecemos que é curta ainda a perspectiva temporal em que se extendem as doutrinas renovadôras; e que é árdua a sua missão, tão árdua como bemfazejos hão-de ser os frutos que os homens do futuro colherão, de ordem e de tranquilidade. 